\title{
Analisis Faktor Hasil Penilaian Budi Pekerti
}

\author{
Hadiwinarto $^{1}$ \\ Fakultas Keguruan dan Ilmu Pendidikan Universitas Bengkulu
}

\begin{abstract}
The purpose of this study was to describe the load factor of the assessment results on character education for high school students. The subjects were 545 second grade students. There were four instruments used, namely: cognitive aspect, affective aspect, behavioral aspect in the learning process and behavioral aspect outside the learning process. Each aspect contains nine indicators as factors. Data were analyzed with factor analysis technique and the models used were the Confirmatory Model of Principal Components Analysis with the varimak rotation method and Kaiser normalization. The results showed that each of these factors were statistically independent, not associated with other indicators. These findings reinforced the theories used in this study that character education loads indicators of dedication, conviction, honesty, discipline, tolerance, democracy, sense of belonging, gratitude and empathy. Statistically, each indicator obviously has four aspects of character. Therefore, assessment of manners that includes the aspects of cognitive, affective and behavior is a task that absolutely must be done.
\end{abstract}

Keywords: character, factor analysis, cognitive, affective and behavioral

Abstrak. Penelitian ini bertujuan untuk mendeskripsikan muatan faktor hasil penilaian pendidikan budi pekerti siswa di Sekolah Menengah Atas. Sampel penelitian 545 orang siswa kelas dua. Ada empat instrumen yang digunakan, yakni: instrumen aspek kognitif, aspek afektif, aspek perilaku didalam proses pembelajaran dan aspek perilaku di luar proses pembelajaran. Masing-masing aspek mengandung sembilan indikator sebagai faktor. Data dianalisis menggunakan teknik analisis faktor, dan model yang digunakan adalah teknik principal components analysis model confirmatory dengan rotasi metode varimak dengan Kaiser normalization. Hasil penelitian menunjukkan bahwa masing-masing faktor secara statistik bersifat independen, tidak terkait dengan indikator yang lainnya. Temuan ini memperkuat teori-teori yang digunakan dalam penelitian ini bahwa pendidikan budi pekerti memuat indikator-indikator pengabdian, keyakinan, kejujuran, kedisiplinan, toleransi, demokrasi, rasa memiliki, syukur, dan empati. Secara statistik, masing-masing indikator dengan jelas memuat keempat aspek budi pekerti. Oleh sebab itu, penilaian budi pekerti mencakup aspek kognitif, afektif, dan perilaku merupakan suatu hal yang mutlak harus dilakukan.

Kata kunci: budi pekerti, analisis faktor, kognitif, afektif dan perilaku

Undang-Undang Sistem Pendidikan Nasional Nomor 20 Tahun 2003 pasal 3 menegaskan bahwa pendidikan nasional bertujuan mencerdaskan kehidupan bangsa dan mengembangkan manusia Indonesia seutuhnya, yaitu manusia yang beriman dan bertaqwa kepada Tuhan Yang

\footnotetext{
${ }^{1}$ Korespondensi mengenai isi artikel ini dapat dilakukan melalui: hadiwinarto1309@gmail.com
}

Maha Esa dan berbudi pekerti luhur, memiliki pengetahuan dan keterampilan, kesehatan jasmani dan rohani, kepribadian yang tangguh dan mandiri serta rasa tanggung jawab kemasyarakatan dan kebangsaan. Selanjutnya dalam pasal 39 disebutkan bahwa pendidik merupakan tenaga profesional yang bertugas merencanakan dan melaksanakan proses pembe- 
lajaran, menilai hasil pembelajaran, dan melakukan pembimbingan.

Dalam hal ini pendidik dapat diartikan sebagai guru. Dalam Undang-Undang Sistem Pendidikan Nasional (UUSPN), terkandung makna bahwa setiap guru mempunyai tanggung jawab moral untuk menanamkan nilai-nilai budi pekerti luhur kepada siswa. Secara implisit setiap guru juga mempunyai tugas dan tanggungjawab untuk melakukan penilaian mengenai pengetahuan, pemahaman dan implementasi budi pekerti. Pada hakikatnya manusia adalah makhluk yang berakal budi, makhluk pribadi, makhluk sosial, dan makhluk yang berbudaya. Pendidikan bertujuan untuk memanusiakan manusia, atau membantu proses hominisasi dan humanisasi. Artinya membantu orang muda untuk semakin menjadi manusia, manusia yang bernilai tinggi, berbudaya tinggi dan bermoral, berkarakter, bertanggung jawab, dan bersosialisasi. Hal ini karena pendidikan merupakan fenomena insani (Driyarkara, 2006). Pendapat ini mengandung makna bahwa dalam proses pendidikan formal, setiap guru tidak hanya membimbing, mengarahkan dan memberikan pengetahuan, pemahaman dan keterampilan tentang ilmu pengetahuan dan teknologi kepada siswa, akan tetapi juga melaksanakan pendidikan moral sebagai bekal untuk menjadi makhluk sosial, makhluk individual, dan makhluk yang berke-Tuhanan.

Pendidikan budi pekerti menjadi sangat penting untuk penanaman nilai-nilai moral dan nilai-nilai sosial kepada siswa agar berbudi pekerti luhur. Kurangnya pengetahuan dan pemahaman guru dalam mengajarkan pendidikan budi pekerti, pemahaman yang sempit tentang budi pekerti, ketidakmampuan dan belum terbiasanya guru menambahkan pelajaran dengan nilai-nilai budi pekerti, kurangnya wibawa guru merupakan faktor penghambat untuk menjadikan diri guru sebagai teladan (Afif, 2001). Terjadinya penyimpangan moral siswa di sekolah, tidak dapat hanya dilimpahkan kepada guru pendidikan agama, tetapi juga merupakan tanggung jawab seluruh pendidik di sekolah. Ibung (2009) mengatakan bahwa moral adalah suatu keyakinan tentang benar salah, baik dan buruk, yang sesuai dengan kesepakatan sosial, yang mendasari tindakan atau pemikiran. Normanorma moral adalah tolok ukur yang digunakan masyarakat untuk mengukur kebaikan seseorang. Selanjutnya dijelaskan bahwa ada nilai-nilai sosial budaya yang merupakan rangkaian dari konsep-konsep abstrak yang hidup di dalam alam pikiran sebagian besar dari warga masyarakat mengenai apa yang baik dan apa yang buruk dan norma-norma yang mengatur kegiatan-kegiatan manusia untuk mencapai citacita. Nilai-nilai sosial budaya tadi berfungsi sebagai pedoman dan pendorong perilaku individu di dalam hidupnya.

Aeni dan Sudaryanto (2005) menyimpulkan bahwa evaluasi pendidikan budi pekerti yang dilakukan oleh pamong yang terkait dengan pembelajaran masih cenderung mengukur ketercapaian aspek kognitif (kecerdasan), kurang memperhatikan aspek afektif dan psikomotorik. Temuan ini mengindikasikan bahwa muatan pendidikan budi pekerti belum sesuai dengan hakikat pendidikan budi pekerti. Ada empat model untuk menanamkan nilainilai moral kehidupan manusia sebagai makhluk pribadi, berakal, dan berbudaya, yakni: model sebagai mata pelajaran tersendiri, model terintegrasi dalam semua bidang studi, model diluar pengajaran, dan model gabungan (Suparno, Koesoemo, Titisari, \& Kartono, 2002). Mulyana (2004), mengemukakan bahwa setiap pengajaran dan bimbingan yang dilaku- 
kan pendidik sudah tentu melibatkan proses penyadaran nilai-nilai. Sekolah memiliki norma-norma yang harus dipahami dan ditaati. Pada umumnya nilai-nilai yang dianut di sekolah sejalan dengan yang berlaku dalam masyarakat sekitarnya. Dengan demikian, institusi pendidikan atau sekolah harus menjadi lingkungan yang kondusif. Hal ini sejalan dengan apa yang dikemukakan Sardiman (2010) bahwa sekolah harus menjadi sebuah komunitas dan wahana persaudaraan tempat berkembangnya nilai-nilai kebaikan atau nilai-nilai utama. Budi pekerti siswa di sekolah mempunyai korelasi positif yang signifikan dengan prestasi belajar mata pelajaran Pendidikan Kewarganegaraan, Sosiologi, Pendidikan Agama, dan Bahasa Indonesia (Hadiwinarto, 2009).

Berdasarkan uraian di atas, jelaslah bahwa hakikat budi pekerti mencakup tiga aspek, yaitu: (1) aspek kognitif atau pemahaman atau pengetahuan, (2) aspek afektif atau emosi dan perasaan, dan (3) aspek perilaku. Hasil pendidikan budi pekerti merupakan bagian yang integral dari hasil pendidikan pada umumnya. Pendidikan budi pekerti sebagai muatan pendidikan pada jalur pendidikan formal di Indonesia, menjadi sangat penting, sekaligus juga sangat kompleks. Kompleksnya pendidikan budi pekerti itu terkait dengan beberapa persoalan. Pertama, pendidikan budi pekerti bukan merupakan mata pelajaran tersendiri, tetapi terkandung di dalam semua mata pelajaran, dan dalam pergaulan di luar jam pelajaran. Pendidikan budi pekerti tidak harus merupakan satu mata pelajaran, karena materi budi pekerti secara eksplisit sudah terkandung di dalam mata pelajaran Pendidikan Agama, mata pelajaran Pendidikan Kewarganegaraan, dan sebagian di dalam mata pelajaran Sosiologi. Kedua, setiap guru mempunyai tanggung- jawab moral untuk melaksanakan pendidikan budi pekerti melalui pengajaran mata pelajaran yang diajarkannya. Setiap guru bukan hanya harus melaksanakan pendidikan budi pekerti, akan tetapi juga harus bertanggungjawab untuk melakukan penilaian budi pekerti siswa.

\section{Pendidikan Budi Pekerti}

Pendidikan budi pekerti juga disebut pendidikan nilai, merupakan suatu hal yang sangat berharga bagi kehidupan umat manusia di seluruh dunia. Pendidikan nilai didalam institusi formal, non formal dan informal di semua kelompok masyarakat, negara dan bangsa, esensinya adalah sesuatu hal yang baik bagi kehidupan manusia, meskipun di antara mereka memiliki standar nilai yang berbeda. Sebagaimana dikemukakan oleh Suparlan (2007) bahwa mendidik yang menekankan pada pengembangan moral kejujuran, menjadi sasaran utama pencerdasan emosional peserta didik, yang harus dipertanggungjawabkan oleh guru bersama semua komponen sekolah. Fakta menunjukkan bahwa setiap mata pelajaran mengandung potensi moral kejujuran, karena mata pelajaran adalah suatu bentuk ilmu, sedangkan ilmu itu sendiri, apapun jenisnya selalu berisi tentang kebenaran. Pendapat Suparlan ini mempertegas bahwa pendidikan budi pekerti bagi siswa di sekolah merupakan tanggung jawab semua guru bidang studi bersama-sama komponen sekolah lainnya.

Berkenaan dengan hal ini, Kawsar (2004) mengemukakan bahwa pengajaran untuk toleransi, rasa hormat dan pengenalan dalam hubungan dengan agama atau kepercayaan, dapat diterapkan oleh guru dalam menghadapi anak-anak dari agama yang berbeda. Untuk memperjelas pemahaman mereka, Kementerian Pendidikan melalui pengenalan suatu hal yang 
baru berkaitan dengan moral dan nilainilai kehidupan sehari-hari untuk meyakinkan anak-anak bahwa semua agama percaya mendukung nilai-nilai yang sama. Dengan begitu anak-anak merasakan kesatuan di antara mereka dan keraguan mereka sudah akan mengecil. Zakaria (2001), mengemukakan bahwa pendidikan budi pekerti memiliki esensi dan makna yang sama dengan pendidikan moral dan pendidikan akhlak. Tujuannya adalah membentuk pribadi anak supaya menjadi manusia yang baik, warga masyarakat, dan warga negara yang baik. Nilai-nilai adalah tidak hanya terkait dengan kepercayaan, tetapi juga dengan pemahaman, perasaan, dan perilaku.

Pengertian budi pekerti secara operasional adalah upaya untuk membekali peserta didik melalui kegiatan bimbingan, pengajaran dan latihan selama pertumbuhan dan perkembangan dirinya sebagai bekal masa depan agar memiliki hati nurani yang bersih, berperangai baik, yang tercermin pada perilaku berupa ucapan, perbuatan, sikap pikiran, perasaan, kerja dan hasil karya berdasarkan nilai-nilai agama serta norma dan moral (Setyowati, 2009). Pendidikan budi pekerti merupakan pendidikan yang terintegrasi dengan setiap bahan ajar, dan menjadi tanggung jawab bersama antara lembaga pendidikan sekolah dan luar sekolah (Murtadlo, 2009). Oleh karena itu, ia bukanlah suatu bahan ajar yang berdiri sendiri dan dilaksanakan oleh sebagian pihak saja, misalnya hanya oleh sekolah.

Cahyoto (2002) mengemukakan bahwa pendidikan budi pekerti memiliki beberapa tujuan yang dapat dijelaskan sebagai berikut: (1) mendorong kebiasaan berperilaku terpuji sesuai nilai-nilai universal dan tradisi budaya yang religius; (2) menanamkan jiwa kepemimpinan dan tanggung jawab; (3) memupuk ketegaran mental peserta didik agar tidak terjerumus pada perilaku yang menyimpang, baik secara individu maupun sosial, dan (4) meningkatkan kemampuan untuk menghindari sifat tercela yang dapat merusak diri sendiri, orang lain, dan lingkungan. Budi pekerti lebih menitikberatkan pada karakter, perangai, perilaku atau dengan kata lain tata krama dan etika (Ryi, 2000). Jadi pendidikan budi pekerti dapat diartikan sebagai penanaman nilai-nilai akhlak, tata krama, bagaimana berperilaku baik pada orang lain. Pada perkembangannya pendidikan budi pekerti tidak hanya melibatkan relasi sosial anak, tetapi juga melibatkan pengetahuan, perasaan dan perilaku anak yang berada dalam ranah pendidikan karakter.

Pendidikan moral mencakup pengetahuan, sikap, kepercayaan, keterampilan, dan perilaku yang baik, jujur, dan penyayang dapat dinyatakan dengan istilah bermoral. Menurut Zuchdi (2009), tujuan utama pendidikan moral adalah menghasilkan individu yang mandiri, yang memahami nilai-nilai moral dan memiliki komitmen untuk bertindak konsisten dengan nilai-nilai tersebut. Dalam kaitannya dengan proses pembelajaran di sekolah, maka titik awal pendidikan moral adalah membuat siswa-siswa memahami konsep moralitas. Hal ini karena pendidikan moral mengandung beberapa komponen, yaitu pengetahuan tentang moralitas, penalaran moral, perasaan kasihan dan peduli terhadap kepentingan orang lain, dan tendensi moral (Zuchdi, Prasetya, \& Masruri, 2013).

Ki Hadjar Dewantara mengartikan pendidikan sebagai daya upaya memajukan budi pekerti, pikiran serta jasmani anak, agar dapat memajukan kesempurnaan hidup, yaitu hidup dan menghidupkan anak yang selaras dengan alam dan masyarakatnya (Wardani, 2010). Para 
pakar pendidikan menilai bahwa setiap praktik pendidikan diarahkan pada pencapaian tujuan-tujuan tertentu, apakah berkenaan dengan penguasaan pengetahuan, pengembangan pribadi, kemampuan sosial atau kemampuan kerja. Untuk menyampaikan bahan pelajaran, ataupun mengembangkan kemampuan-kemampuan tersebut diperlukan metode penyampaian serta alat bantu tertentu. Demikian juga untuk menilai proses dan hasilnya (Murtadlo, 2009).

Sebagaimana telah dikemukakan di atas bahwa perilaku yang dipelajari atau dibentuk melalui proses pendidikan, yakni pendidikan budi pekerti dengan cara penanaman nilai-nilai moral dan nilai-nilai sosial kehidupan. Ada empat model untuk menanamkan nilai-nilai moral kehidupan manusia sebagai makhluk pribadi, berakal, sosial, dan berbudaya, yakni; model sebagai mata pelajaran tersendiri, model terintegrasi dalam semua bidang studi, model di luar pengajaran, dan model gabungan (Suparno, dkk, 2002).

Tillman (2004) menyusun suatu program pendidikan nilai yang disebut "Living Values: An Educational Program", dengan tujuan: (1) Untuk membantu individu memikirkan dan merefleksikan nilai-nilai yang berbeda dan implikasi praktis bila mengekspresikan nilai-nilai tersebut dalam hubungannya dengan diri sendiri, orang lain, dan masyarakat. (2) Untuk memperdalam pemahaman, motivasi dan tanggungjawab saat menentukan pilihan-pilihan pribadi dan sosial yang positif. (3) Untuk menginspirasi individu memilih nilai-nilai pribadi, sosial, moral dan spiritual dan menyadari metodemetode praktis dalam mengembangkan dan memperdalam nilai-nilai tersebut, dan (4) Untuk mendorong para pengajar dan pengasuh memandang pendidikan sebagai sarana memberikan filsafat-filsafat hidup kepada murid, dengan demikian memfasilitasi pertumbuhan, perkembangan dan pilihan-pilihan mereka sehingga bisa berinteraksi dengan masyarakat dengan rasa hormat, percaya diri dan tujuan yang jelas.

Tilman (2004) juga mengemukakan bahwa semua guru disarankan untuk menambahkan kegiatan menjelajahi nilai ke dalam kurikulum yang sudah ada, untuk anak-anak dan remaja, dengan fokus nilai-nilai; perdamaian, rasa hormat, cinta, kebahagiaan, kejujuran, kesederhanaan, tanggung jawab, kebersahajaan, toleransi, kerja sama, kebebasan, dan persatuan.

Berdasarkan teori-teori di atas, dapat disintesiskan bahwa pendidikan budi pekerti mencakup dua sisi, yakni sisi konseptual dan sisi operasional. Secara konseptual, pendidikan budi pekerti adalah upaya pembentukan, pengembangan, peningkatan pemeliharaan dan perbaikan kesadaran, perasaan, sikap dan pemahaman tentang aturan dan norma peserta didik. Secara operasional, pendidikan budi pekerti adalah upaya membentuk perilaku peserta didik agar kata, perbuatan, dan hasil karya berdasarkan nilai, norma dan moral luhur.

Berdasarkan Buku Pedoman Pendidikan Budi Pekerti, nilai-nilai budi pekerti untuk sekolah menengah umum pada mata pelajaran Pendidikan Pancasila dan Kewarganegaraan, mencakup nilai-nilai keadilan, baik sangka, berani menerima risiko, berpikir jauh ke depan, bijaksana, cerdas, cermat, efisien, empati, hormat, ikhlas, iman, inisiatif, kebersamaan, komitmen, kooperatif, kukuh hati, manusiawi, patriotik, pengabdian, pengendalian diri, ramah, rasa keterikatan, rela berkorban, rendah hati, taat asas, tenggang rasa, dan ulet (Depdiknas, 2003). Sedangkan pada mata pelajaran Pendidikan Agama Islam, 
mecakup: amanah, iman, disiplin, syukur, tanggung jawab, hemat, menghargai kesehatan/kebersihan, pemaaf, pemurah, menghargai waktu, pengabdian, pengendalian diri, rela berkorban, hormat, semangat kebersamaan, taat asas, mawas diri, rasa indah, saleh, kerja keras, lembut hati, konstruktif, keras kemauan, adil, ikhlas, berkepribadian, kesatria, menghargai karya orang lain, rasa keterikatan, rajin, setia, tenggang rasa, berani berbuat benar, berpikir ke depan, dinamis, demokratis, menghargai pendapat orang lain, manusiawi, produktif, patriotik, rasa percaya diri, tangguh, tekun, terbuka, takut berbuat dosa, dan berani menerima risiko (Depdiknas, 2003).

Kawsar (2004) juga mengemukakan bahwa nilai-nilai yang harus dimiliki siswa dalam belajar adalah nilai-nilai untuk mencintai sesama, bekerjasama, menghargai persahabatan, cara bertanggungjawab, menjadi baik hati dan adil, menjadi jujur apa yang mereka katakan dan lakukan, belajar pentingnya kebebasan untuk semua orang, hubungan dengan orang lain, hak/kebenaran seseorang, hubungan antara tugas-tugas, cara menghormati dirinya dan orang lain, bersama-sama lebih kuat daripada sendiri, mengeluarkan pendapat untuk memecahkan permasalahan, menghargai hidup secara damai, menikmati kebahagiaan, menghindari kekerasan, mengetahui bahwa manusia mempunyai harga diri dan martabat, menghormati kebenaran, menikmati sukses, dan merasakan bahagia atas kesuksesan.

Berdasarkan beberapa pendapat mengenai pendidikan dan penilaian budi pekerti yang telah dipaparkan di atas, dapat disimpulkan bahwa penilaian budi pekerti setidaknya mencakup sembilan indikator, yakni: keyakinan, syukur, kejujuran, rasa memiliki, kedisiplinan, toleransi, empati, pengabdian dan demokrasi.

\section{Penilaian Budi Pekerti}

Pendidikan budi pekerti yang merupakan bagian integral dari pendidikan formal di sekolah, perlu dilakukan evaluasi. Penilaian budi pekerti terkait dengan persoalan materi pendidikan budi pekerti di sekolah. Oleh sebab itu, isi alat atau instrumen penilaian budi pekerti juga harus mengenai nilai-nilai moral, nilainilai sosial, sikap, emosi dan perasaan, minat, motivasi, perilaku, dan pengetahuan. Mulyana (2004) mengemukakan bahwa materi pendidikan budi pekerti dalam kurikulum pendidikan di sekolah tidak merupakan mata pelajaran tersendiri, tetapi terintegrasi ke dalam semua mata pelajaran, dan dalam pergaulan di luar jam pelajaran. Artinya, bahwa setiap pengajaran dan bimbingan yang dilakukan pendidik sudah tentu melibatkan proses penyadaran nilai-nilai. Akan tetapi, mengingat keberadaan materi pendidikan budi pekerti yang tidak secara khusus, maka konsekuensinya tidak ada guru yang mempunyai tanggung jawab formal melaksanakan penilaian terhadap hasil pendidikan budi pekerti.

Terkait hal ini Djaali (2002) menyatakan bahwa sampai saat ini masih banyak dijumpai kesulitan dalam mengukur mutu pendidikan di Indonesia, sehingga tolok ukur akhlak dan moral misalnya, para guru di lapangan masih belum dapat melakukan evaluasi yang standar, sehingga terkadang menjadi alasan untuk mengabaikan proses pendidikan nilai dan akhlak di sekolah. Penelitian Rufran dan Hadiwinarto (2005) menemukan bahwa penilaian budi pekerti siswa di sekolah menengah atas belum dilakukan secara menyeluruh pada semua aspek, karena hanya dilakukan melalui pengamatan terhadap perilaku siswa. Penilaian budi pekerti terutama diarahkan untuk memperbaiki perilaku anak, namun juga dapat 
dipergunakan untuk keperluan lain, seperti kenaikan kelas dan sebagai bahan pertimbangan untuk keperluan tertentu (Afif, 2001).

Ada tiga pertanyaan utama dalam penilaian budi pekerti siswa di sekolah, yakni: pertama, apa yang dinilai; kedua, siapa yang melakukan penilaian; dan ketiga, kapan atau dalam peristiwa apa penilaian itu dilakukan. Berdasarkan hakikat budi pekerti sebagaimana telah diuraikan di atas, maka penilaian terhadap hasil pendidikan budi pekerti mencakup ranah kognitif, afektif, dan perilaku.

Observasi merupakan cara yang tepat untuk menilai aspek perilaku. Sebagaimana penelitian Morrison, Forress, dan MacMillan (dalam Kerlinger, 2002) yang menggunakan sampling-waktu untuk merekam/mencatat perilaku semua anak dalam suatu ruangan kelas. Secara rutin dan teratur, perilaku setiap anak diobservasi selama interval enam-detikan, hingga sedikitnya sepuluh interval untuk perilaku setiap anak setiap hari telah terekam (Kerlinger, 2002). Metode lain yang dapat digunakan adalah dengan cara mengajukan pertanyaan-pertanyaan khusus dalam wawancara atau pada inventori laporan diri sendiri. Asumsi metode ini adalah bahwa responden lebih mengetahui tentang sikapnya sendiri dan mengungkapkannya kepada pewawancara. Menurut Mardapi (2011), melalui metode ini informasi yang diperoleh berupa nilai dan keyakinan yang positif dan yang negatif. Hal-hal yang positif diperkuat sedang yang negatif diperlemah dan akhirnya dihilangkan.

Berdasarkan uraian di atas, maka permasalahan yang mendasari perlunya penelitian ini dilakukan adalah apakah penilaian budi pekerti siswa di sekolah mengungkap semua indikator budi pekerti. Mengingat sangat pentingnya pendi- dikan budi pekerti siswa di sekolah, maka perlu dilakukan penelitian dengan menganalisis muatan atau faktor-faktor dalam pendidikan budi pekerti menggunakan instrumen yang memuat semua indikator budi pekerti. Tujuan penelitian ini untuk mendeskripsikan muatan faktor hasil penilaian pendidikan budi pekerti siswa di sekolah menengah atas.

\section{Metode}

Penelitian ini mendeskripsikan secara statistik muatan pendidikan budi pekerti berdasarkan faktor-faktornya. Jumlah sampel penelitian 545 orang siswa kelas dua dari lima sekolah menengah atas negeri di Provinsi Bengkulu. Instrumen yang digunakan untuk pengumpulan data adalah instrumen penilaian budi pekerti yang terdiri atas 225 butir. Instrumen tersebut terdiri atas empat aspek, yakni: (1) Aspek afektif berupa kuesioner, memiliki koefisien validitas butir terendah 0,173 dan tertinggi 0,645; koefisien reliabilitas 0,916. (2) Aspek kognitif berupa tes, memiliki koefisien validitas butir terendah 0,123 dan tertinggi 0,607 , koefisien reliabilitas 0,849. (3) Aspek perilaku di dalam proses pembelajaran berupa checklist, memiliki koefisien validitas butir terendah 0,124 dan tertinggi 0,628 dan koefisien reliabilitas 0,942, dan (4) Aspek perilaku di luar proses pembelajaran berupa checklist, memiliki koefisien validitas butir terendah 0,130 dan tertinggi 0,604 dan koefisien reliabilitas 0,843 (Hadiwinarto, 2009). Penilaian budi pekerti aspek kognitif dan aspek afektif dilakukan oleh siswa sendiri, penilaian aspek perilaku di dalam proses pembelajaran dilakukan oleh guru bidang studi, dan penilaian aspek perilaku di luar proses pembelajaran dilakukan oleh tata usaha sekolah, guru bimbingan konseling, dan guru pembina kegiatan kesiswaan. 
Data dianalisis dengan menggunakan teknik analisis faktor. Analisis faktor utamanya dipergunakan untuk mereduksi data atau meringkas dari variabel yang banyak diubah menjadi sedikit variabel baru yang disebut faktor dan masih memuat sebagian besar informasi yang terkandung dalam variabel asli (Supranto, 2004). Analisis faktor adalah analisis statistik yang digunakan untuk menemukan beberapa faktor yang mendasari dan mengungkapkan saling keterkaitan diantara variabel. Analisis ini bertujuan untuk mengetahui hubungan interkorelasi di antara sejumlah besar variabel dengan cara mengidentifikasi satu set dimensi pokok yang sama (Srinadi \& Nilakusmawati, 2008).

Dua model dalam analisis faktor, yakni: model confirmatory dan model exploratory. Model yang digunakan adalah teknik principal components analysis model confirmatory dengan rotasi metode varimak dengan kaiser normalization. Instrumen yang digunakan disusun berdasarkan konstruknya, yakni kajian-kajian teoretik tentang materi pendidikan budi pekerti. Principal components analysis adalah teknik statistik yang digunakan untuk satu set variabel untuk melihat variabel-variabel mana yang membentuk satu sub-tes tetapi bebas dari subtes-subtes lainnya (Tabachnik \& Fidell, 2007).

Untuk keperluan analisis faktor, maka aspek-aspek penilaian budi pekerti selanjutnya disebut sebagai faktor. Melalui analisis faktor, sejumlah skor butir di dalam satu indikator direduksi hingga beberapa iterasi. Iterasi terakhir merupakan bukti bahwa skor butir-butir faktor yang tetap berada di dalam indikatornya adalah betul-betul bersifat independen tidak terkait dengan indikator lainnya.

\section{H a s i 1}

Untuk keperluan analisis faktor dengan aspek penilaian sebagai faktor, maka data disusun berdasarkan indikatornya. Penilaian budi pekerti siswa di sekolah mencakup sembilan indikator. Masingmasing indikator terdiri atas empat faktor, yakni: faktor afektif, faktor kognitif, faktor perilaku di dalam proses pembelajaran, dan faktor perilaku di luar proses pembelajaran. Sebaran jumlah butir masingmasing indikator ke dalam empat faktor, disajikan pada Tabel 1.

Hasil perhitungan analisis faktor terhadap data butir masing-masing indikator dengan menggunakan bantuan Program SPSS for Windows Versi 12.0, terangkum dalam Tabel 2. Setelah dikonfirmasi, ternyata pada masing-masing indikator terdapat kesamaan antara sebaran butirbutir indikator atas dasar konstruknya dengan hasil analisis faktor.

Temuan ini membuktikan bahwa muatan pendidikan budi pekerti pada masing-masing indikator bersifat indipenden tidak terkait dengan indikator lain, setiap indikator tetap memuat keempat faktor.

\section{Diskusi}

Pendidikan budi pekerti di sekolah diketahui secara umum bukan sebagai mata pelajaran tersendiri. Pemberian pendidikan budi pekerti di sekolah menjadi tanggung jawab semua guru dan personil sekolah. Oleh sebab itu, penilaian terhadap budi pekerti siswa di sekolah juga harus dilakukan oleh semua personil sekolah. 
Tabel 1

Sebaran jumlah butir masing-masing indikator ke dalam faktor

\begin{tabular}{|c|c|c|c|c|c|c|}
\hline \multirow[b]{2}{*}{ No. } & \multicolumn{6}{|c|}{ Butir-butir Faktor } \\
\hline & Indikator & Afektif & Kognitif & $\begin{array}{l}\text { Perilaku di } \\
\text { dalam PBM }\end{array}$ & $\begin{array}{c}\text { Perilaku di } \\
\text { luar PBM }\end{array}$ & $\begin{array}{l}\text { Jmlh } \\
\text { Butir }\end{array}$ \\
\hline 1. & Pengabdian & 8 & 6 & 8 & 9 & 31 \\
\hline 2. & Kejujuran & 8 & 7 & 8 & 7 & 30 \\
\hline 3. & Toleransi & 8 & 8 & 9 & 8 & 33 \\
\hline 4. & Keyakinan & 7 & 6 & 8 & 5 & 26 \\
\hline 5. & Rasa Memiliki & 7 & 5 & 7 & 7 & 26 \\
\hline 6. & Kedisiplinan & 7 & 5 & 9 & 8 & 29 \\
\hline 7. & Demokrasi & 6 & 6 & 5 & 6 & 23 \\
\hline 8. & Syukur & 5 & 3 & 3 & 3 & 14 \\
\hline 9. & Empati & 4 & 4 & 3 & 2 & 13 \\
\hline & Total & 60 & 50 & 60 & 55 & 225 \\
\hline
\end{tabular}

Tabel 2

Rangkuman hasil analisis faktor terhadap 9 indikator penilaian budi pekerti

\begin{tabular}{lccccccc}
\hline Aspek & Butir & MSA & Chi-Square & df & Sig. & Iterasi & Konfirmasi \\
\hline Pengabdian & 31 & 0,868 & 26593,781 & 465 & 0,000 & 5 & Oke \\
Kejujuran & 30 & 0,719 & 27561,180 & 435 & 0,000 & 5 & Oke \\
Toleransi & 33 & 0,789 & 27084,479 & 528 & 0,00 & 5 & Oke \\
Keyakinan & 26 & 0,616 & 25366,668 & 325 & 0,000 & 5 & Oke \\
Rasa memiliki & 26 & 0,706 & 18530,383 & 325 & 0,000 & 5 & Oke \\
Kedisiplinan & 29 & 0,664 & 31156,857 & 406 & 0,000 & 5 & Oke \\
Demokrasi & 23 & 0,781 & 25239,038 & 253 & 0,000 & 5 & Oke \\
Syukur & 14 & 0,755 & 13277,845 & 91 & 0,000 & 4 & Oke \\
Empati & 13 & 0,741 & 6496,988 & 78 & 0,000 & 5 & Oke \\
\hline
\end{tabular}

Secara teoritis, pendidikan budi pekerti memuat sembilan indikator, yakni: indikator keyakinan, indikator syukur, indikator kejujuran, indikator rasa memiliki, indikator kedisiplinan, indikator toleransi, indikator empati, indikator pengabdian dan indikator demokrasi. Pemilihan butir-butir antara indikator yang satu dengan indikator lainnya haruslah jelas, ini diperkuat dengan hasil analisis faktor. Kejelasan eksistensi butir dalam setiap indikator budi pekerti akan memperkuat keharusan betapa komprehensifnya menilai budi pekerti siswa.

Melalui analisis faktor ditemukan penyebaran butir-butir ke sejumlah faktor merupakan bukti adanya struktur hubungan antar variabel yang diteliti. Sebagaimana dikemukakan oleh Supranto (2004) bahwa analisis faktor utamanya dipergunakan untuk mereduksi data atau meringkas dari variabel yang banyak diubah menjadi sedikit variabel baru yang disebut faktor dan masih memuat sebagian besar informasi yang terkandung dalam variabel asli (original variable). Srinadi dan Nilakusmawati (2008) mengemukakan bahwa analisis faktor bertujuan untuk mengetahui hubungan interkorelasi di antara sejumlah besar variabel dengan cara mengidentifikasi satu set dimensi pokok yang sama. 
Dengan mempelajari butir-butir instrumen pada indikator keyakinan, ternyata memuat hal-hal seperti yang dikemukakan oleh Zuchdi (2009) bahwa pendidikan moral mencakup pengetahuan, sikap, kepercayaan, keterampilan, dan perilaku yang baik, jujur, dan penyayang. Mulyana (2004) mengemukakan bahwa nilai adalah rujukan dan keyakinan dalam menentukan pilihan. Nilai adalah standar tingkah laku, keindahan, keadilan, kebenaran, dan efisiensi yang mengikat manusia dan sepatutnya untuk dijalankan dan dipertahankan. Indikator syukur juga memuat hal-hal seperti yang dikemukakan oleh Amin (2004) bahwa syukur, yaitu perasaan yang terus menerus berbudi baik dan penghargaan terhadap kebajikan, yang mendorong hati untuk mencintai dan lisan untuk memuji. Budi pekerti mengandung pengertian antara lain adat istiadat, sopan santun, dan perilaku. Dalam konteks perilaku siswa di sekolah, maka penilaian perilaku dilakukan oleh guru dan personil sekolah lainnya. Agar proses penilaian terfokus, maka dilaksanakan oleh guru bidang studi, pejabat sekolah, maupun staf administrasi sekolah.

Penilaian terhadap aspek afektif dilakukan oleh siswa itu sendiri. Karena pada ranah afektif menyangkut persoalan sikap, emosi, perasaan, motivasi, minat, pengetahuan yang dimiliki siswa sebagai individu. Asumsi dari penilaian melalui metode ini adalah bahwa responden lebih mengetahui tentang sikapnya sendiri dan dapat mengungkapkannya kepada pewawancara. Hal ini sesuai dengan pendapat Mulyana (2004) bahwa penilaian untuk afektif seringkali menghadapi sejumlah kesulitan. Kesulitan itu muncul karena hal yang berkaitan dengan nilai, sikap, minat dan motivasi merupakan kemampuan individu yang hanya diketahui persis oleh orang yang bersangkutan. Meskipun begitu, penilaian aspek afektif harus tetap dilakukan, karena aspek afektif merupakan bagian dari organisme manusia yang tidak bisa dilepaskan.

Berdasarkan hasil analisis faktor, masing-masing indikator memuat faktor afektif, kognitif, perilaku di dalam proses pembelajaran, dan perilaku di luar proses pembelajaran. Temuan ini memperkuat teori bahwa setiap indikator dalam menilai budi pekerti siswa di sekolah harus memuat keempat faktor budi pekerti, yakni faktor afektif, faktor kognitif, faktor perilaku di dalam proses pembelajaran, dan faktor perilaku di luar proses pembelajaran. Sebagaimana dikemukakan oleh Zakaria (2001), bahwa pendidikan budi pekerti memiliki esensi dan makna yang sama dengan pendidikan moral dan pendidikan akhlak. Tujuannya adalah membentuk pribadi anak supaya menjadi manusia yang baik, warga masyarakat, dan warga negara yang baik.

Lebih lanjut Mardapi (2011) mengemukakan bahwa nilai berkaitan dengan keyakinan, sikap dan aktivitas atau tindakan seseorang. Tindakan merupakan refleksi dari nilai yang dianutnya. Selain melalui kuesioner ranah afektif siswa, sikap, minat, konsep diri, dan nilai dapat digali melalui pengamatan. Pengamatan karakteristik afektif siswa dilakukan di tempat terjadinya kegiatan belajar mengajar. Untuk mengetahui keadaan ranah afektif siswa, guru harus menyiapkan diri untuk mencatat setiap tindakan yang muncul dari siswa yang berkaitan dengan indikator ranah afektif siswa.

Penelitian yang dilakukan oleh Murtadlo (2009) menyimpulkan bahwa pendidikan budi pekerti diintegrasikan ke dalam semua mata pelajaran. Dengan demikian akan menghindarkan adanya "mata pelajaran baru, alat indoktrinasi, media penyaluran kepentingan, dan 
pelajaran hafalan yang membosankan." Penilaian dalam pembelajaran terpadu ini adalah penilaian terhadap sosok utuh para siswa. Oleh karena itu, penilaiannya pun memerlukan perhatian khusus karena yang akan ditangkap adalah kemampuan dan kepribadian; alat yang bervariatif seperti portofolio, catatan observasi, wawancara, tes skala sikap, inventori kepribadian, proyektif; waktu yang cukup dan terus menerus; dan keterlibatan semua pihak seperti guru, orang tua, dan masyarakat.

\section{Kesimpulan}

Kesimpulan penelitian ini adalah: (1) penilaian budi pekerti siswa harus mencakup sembilan indikator, yakni: indikator keyakinan, syukur, kejujuran, rasa memiliki, kedisiplinan, toleransi, empati, pengabdian dan demokrasi; (2) kesembilan indikator tersebut, masing-masing bersifat indipenden dan tidak terikat dengan indikator lainnya; dan (3) masing-masing indikator secara teori maupun secara statistik mengandung keempat aspek, yakni: aspek kognitif, afektif, perilaku di dalam proses pembelajaran dan perilaku di luar proses pembelajaran.

\section{Kepustakaan}

Aeni, K., \& Sudaryanto. (2005). Proses Pendidikan Budi Pekerti di Taman Muda Majelis Ibu Pawiyatan Taman Siswa Yogyakarta. Jurnal Pendidikan dan Evaluasi, 1(VII), Program Pascasarjana. Universitas Negeri Yogyakarta.

Afif, Z. (2001). "Pendidikan Budi Pekerti dalam Pelayanan Bimbingan Konseling di Sekolah". Makalah Konvensi Nasional XII IPBI. Bandar Lampung
Amin, M. (2004). Sepuluh Induk Akhlak Terpuji. Jakarta: Kalam Mulia.

Cahyoto. (2002). Budi Pekerti dalam Pespektif Pendidikan. Depdiknas Pendidikan Dasar dan Menengah Pusat Penataran Guru IPS dan PMP Malang.

Departemen Pendidikan Nasional. (2003). Pedoman Umum Pendidikan Budi Pekerti pada Jenjang Pendidikan Dasar dan Menengah. Buku I. Jakarta: Dit. Jend. Dikdasmen

Djaali. (2002). Peningkatan Mutu Pendidikan Nasional di Era Global. Jurnal Penelitian dan Evaluasi Pendidikan, 1(2).

Driyarkara. (2006). Karya Lengkap Driyarkara. A Sudiardja, dkk. (ed.). Yogyakarta: Penerbit Kompas, Gramedia, dan Kanisius.

Hadiwinarto. (2009). Hubungan antara budi pekerti dengan prestasi belajar siswa SMA. Jurnal Pendidikan dan Kebudayaan, 15(6), Balitbang Depdiknas. Jakarta.

Ibung, D. (2009). Mengembangkan Nilai Moral pada Anak. Jakarta: PT Elex Media Komputindo.

Kawsar, K. H. (2004). Teaching for tolerance, respect and recognition in relation with religion or belief. Diunduh dari: http://folk.uio/leirvik/OsloCoalition/K ouchok0904.doc.

Kerlinger. (2002). Asas-asas Penelitian Behavioral. Yogyakarta: Gadjah Mada University Press.

Mardapi, D. (2011). Penilaian Pendidikan Karakter. Dalam Darmiyati Zuchdi (Eds.) Pendidikan Karakter dalam Perspektif Teori dan Praktek (hal. 185 - 211). Yogyakarta: UNY Press.

Mulyana, R. (2004). Mengartikulasikan Pendidikan Nilai. Bandung: Alfabeta.

Murtadlo, A. (2009). Pendekatan Nilai: Kajian atas Implementasi Pendidikan 
Budi Pekerti dalam Proses Pembelajaran. Innovatio, VIII(1), 107-122.

Rufran, Z., \& Hadiwinarto. (2005). Pelaksanaan Pendidikan Budi Pekerti Siswa SMA Negeri di Kota Bangkulu. Laporan Penelitian. Tidak Dipublikasikan. Lembaga Penelitian Universitas Bengkulu.

Ryi. (2000). Pendidikan Nilai untuk Pembentukan Karakter Manusia. Harian Kompas, Rabu 3 Mei.

Sardiman. (2010). Problematika dalam Pendidikan Karakter. Proceeding Seminar Nasional dalam Rangka Dies Natalis UNY Ke-46. Kerjasama FISE UNY dengan SKH Kedaulatan Rakyat. 12 Mei 2010. 17-27.

Setyowati, E. (2009). Pendidikan Budi Pekerti menjadi Mata Pelajaran di Sekolah. Lembaran Ilmu Kependidikan, 39(2), 148-154.

Soedijarto. (2003). Мепијu Pendidikan Nasional yang Relevan dan Bermutu. Jakarta: Balai Pustaka.

Srinadi \& Nilakusmawati. (2008). Faktorfaktor Penentu Kepuasan Mahasiswa terhadap Pelayanan Fakultas sebagai Lembaga Pendidikan. (Studi Kasus di FMIPA, Universitas Udayana). Cakrawala Pendidikan, XXVII(3), 217-231.

Suparlan, S. (2007). Filsafat Pendidikan. Yogyakarta: Ar-Ruzz Media.

Suparno, P., Koesoemo, M.Y., Titisari, D., \& Kartono, St. (2002). Pendidikan Budi Pekerti di Sekolah. Yogyakarta: Kanisius.

Supranto, J. (2004). Analisis Multivariat: Arti dan Interpretasi. Jakarta: Rineka Cipta.
Tabachnik, B. G., \& Fidell, L. S. (2007). Using Multivariate Statistics (5 $5^{\text {th }}$ ed.). Boston: Allyn \& Bacon/Pearson Education.

Tillman, D. (2004a). Alih Bahasa: Adi Respati; Airy Sukidjo. Living Values: An Educational Program: Living Values Activities for Children. Jakarta: PT. Grasindo.

Tillman, D. (2004b). Alih Bahasa: Agustine R.E. Living Values: An Educational Program: Living Values Parent Groups: A Facilitator Guide. Jakarta: PT. Grasindo.

Undang-Undang Republik Indonesia Nomor 20 Tahun 2003. Sistem Pendidikan Nasional. Jakarta.

Wardani, K. (2010). Peran Guru dalam Pendidikan Karakter menurut Konsep Pendidikan Ki Hadjar Dewantara. Proceedings of The 4th International Conference on Teacher Education; Join Conference UPI \& UPSI Bandung, Indonesia, $230-239$.

Zakaria, T. R. (2001). "Pendekatan-pendekatan Pendidikan Nilai dan Implementasi Pendidikan Budi Pekerti". Diunduh dari: www.pdk.go.id/ balitbang/publikasi/jurnal tanggal 13 Juni 2014.

Zuchdi, D. (2009). Humanisasi Pendidikan: Menemukan Kembali Pendidikan yang Manusiawi. Jakarta: Bumi Aksara.

Zuchdi, D., Prasetya, Z. K., \& Masruri, M. S. (2013). Model Pendidikan Karakter: Terintegrasi dalam Pembelajaran dan Pengembangan Kultur Sekolah. Yogyakarta: Multi Presindo. 